\title{
Impacts of Agricultural Cooperatives on Farmers' Revenues in Cambodia: A Case Study of Tram Kak District, Takeo Province
}

\author{
Sereynithia Hun ${ }^{1}$, Shoichi Ito ${ }^{2}$, Hiroshi Isoda ${ }^{2} \&$ Yuichiro Amekawa ${ }^{2}$ \\ ${ }^{1}$ Graduate School of Bioresource and Bioenvironmental Sciences, Kyushu University, Fukuoka, Japan \\ ${ }^{2}$ Faculty of Agriculture, Kyushu University, Fukuoka, Japan \\ Correspondence: Sereynithia Hun, Graduate School of Bioresource and Bioenvironmental Sciences, Kyushu \\ University, Fukuoka-Shi, Higashi-Ku, Hakozaki 6-10-1, 812-8581, Japan. Tel: 81-92-642-2964. E-mail: \\ sereynithia@gmail.com
}

Received: November 6, 2017

Accepted: December 7, $2017 \quad$ Online Published: January 15, 2018

doi:10.5539/jas.v10n2p82

URL: https://doi.org/10.5539/jas.v10n2p82

\begin{abstract}
Agricultural cooperatives in Cambodia have been promoted with the aim of increasing agricultural production and farmers' revenues. The objectives of this study are to identify factors influencing farmers' decision on membership in agricultural cooperatives, and to assess the impact of being a member in those cooperatives on farmers' revenues from paddy, livestock and farm. Cross-sectional data from interviews of 242 households in Tram Kak District, Takeo Province were used. The probit model and propensity score matching were employed to achieve the objectives. The results show that farmers who sold their paddy and had been contacted by extension workers from the government agency and non-governmental organizations (NGOs) are more likely to join the cooperatives while male-headed household farmers and farmers who have high off-farm income are less likely to become members of the cooperatives. Moreover, the results of propensity score matching reveal that agricultural cooperatives have no impact on paddy yields and paddy revenue due to the fact that agricultural cooperatives do not provide sufficient training to their members, and members did not actively attend those trainings provided. Also, the cooperatives have failed to provide members better prices for their paddy. There are positive impacts on their livestock and farm revenues through increasing livestock and other crop production when agricultural cooperatives provide livestock and other crop training to their members. However, there is no impact on non-members if they join the cooperatives as they have higher off-farm income, less paddy land size and fewer laborers that are not favorable to taking on other farming activities.
\end{abstract}

Keywords: agricultural cooperatives, farmers’ revenues, propensity score matching, Cambodia

\section{Introduction}

The population of Cambodia was estimated at 14.68 million in 2013 (National Institute of Statistics [NIS], 2013). Among the total 3.16 million households, 2.5 million households lived in rural areas (Asian Development Bank [ADB], 2014). Agriculture shared more than $30 \%$ of the gross domestic product (GDP) (Ministry of Agriculture, Forestry and Fisheries [MAFF], 2015), and it employed approximately $45.3 \%$ of the total workforce in 2014 (MAFF, 2016). Cultivated areas for agriculture in Cambodia were estimated at 3.7 million hectares, of which three quarters were used for paddy, a staple crop and source of income for most farmers, and the remaining areas were used for producing other food and industrial crops (Food and Agricultural Organization [FAO], 2014). Due to the significance of agriculture in Cambodia, MAFF has initiated programs to promote the agricultural cooperative movement in the country. These programs are intended to boost agricultural production, diversify crop production, create income-generating activities through business development and also expand markets for commercializing all kinds of agricultural products produced by the cooperative members (MAFF, 2008). The development of agricultural cooperatives has been in focus in order to ease the development of agriculture sector, to collectively link with private sectors, to gain technology and credit, to stabilize the food supply to local and international markets, and especially to develop agricultural cooperatives as rural agricultural enterprises with the purpose of improving rural socio-economics (MAFF, 2016).

Between 2003 and 2015, as many as 750 agricultural cooperatives were established and registered at MAFF with 78,126 members throughout the country (MAFF, 2016). Agricultural cooperatives have been promoted in Cambodia since 2003; however, very limited studies have been conducted regarding the impact of membership 
in agricultural cooperatives on yield, paddy revenue, livestock revenue and farm revenue in Cambodia. This study has two objectives: 1) to identify factors influencing farmers' decision on membership in agricultural cooperatives, and 2) to assess the impact of being a member in agricultural cooperatives on farmers' revenues from paddy, livestock and farm.

\section{Research Methodology}

\subsection{Study Site and Data Collection}

The data collection was conducted in September and October 2016 in Tram Kak District, Takeo Province. A total of 242 farmers ( 99 members from 10 agricultural cooperatives and 143 non-members) were randomly selected and interviewed using face-to-face structured interviews. Qualitative interviews were also conducted with directors of those agricultural cooperatives in order to understand more about the situations and problems they have faced. Takeo Province is located in the southern part of Cambodia, and it is one of the most important paddy-producing provinces in the country. According to MAFF annual report 2016, this province has 88 agricultural cooperatives, the largest number of agricultural cooperatives among various provinces in Cambodia. Takeo Province has 10 districts and, based on data obtained from the Cambodian MAFF, Tram Kak District has the largest number of agricultural cooperatives in this province with a population of 181,258 (National Committee for Sub-National Democratic Development [NCDD], 2010). All agricultural cooperatives having paddy business in this district were selected. In addition, these agricultural cooperatives also had some agricultural training such as paddy, livestock and other crop production training.

\subsection{Empirical Models}

For the first objective, a probit model was used to identify factors influencing farmers' decision on membership in agricultural cooperatives. Age, gender, education of household head, household size, paddy land size, paddy sale, off-farm income, TV, car, contact with extension workers and access to a good road were used as independent variables (Table 1). For the second objective, the propensity score matching, (PSM) using the single nearest neighbor matching, was employed to assess the impact of being a member in agricultural cooperatives on paddy yield, paddy revenue per hectare, livestock and farm revenues per year (Table 1).

In order to acquire a realistic estimation of adoption impact, we needed to set a control group with similar attributes as much as possible similar to those of the treated group (Monteiro, 2010). According to Rosenbaum and Rubin (1983), PSM has become the common approach used in impact evaluation as it can control the observable characteristics of the control group as a resemblance of the treated group, that is to say it is a method that could establish a counterfactual condition and reduce possible selection bias involved with observable characteristics.

PSM is a two-step procedure (Becker \& Ichino, 2002). In first step, the probit model is used for the decision to become a member of an agricultural cooperative, and this will provide a propensity score for each observation. Propensity scores of farmers were calculated by estimating the probability model in the probit model, specified as:

$$
y(1 ; 0)=\beta_{0}+\beta_{1} X_{1}+\beta_{2} X_{2}+\ldots \beta_{n} X_{n}
$$

where, $y$ is a dependent variable $(1=$ member of agricultural cooperative; $0=$ non-member $), \beta$ is the regression coefficient to be estimated, and $X$ is an independent variable to be explained. $X_{1}$ is the age of household head, $X_{2}$ is the gender of household head, $X_{3}$ is the years of education of household head, $X_{4}$ is the number of household members, $X_{5}$ is paddy land size, $X_{6}$ is paddy sale, $X_{7}$ is annual income of household head from off-farm job, $X_{8}$ is household having TV, $X_{9}$ is household having car, $X_{10}$ is having contact with extension workers related to agricultural cooperatives, and $X_{11}$ is access to good road in village (Table 1).

After estimating the probability model, we estimate the propensity score based on the following equation:

$$
P_{\text {score }}=1 /\left[1+e^{-\left(\beta_{0}+\beta_{1} X_{1}+\beta_{2} X_{2}+\ldots \beta_{n} X_{n}\right)}\right]
$$

where, $\left(\beta_{0}+\beta_{1} X_{1}+\beta_{2} X_{2}+\ldots \beta_{n} X_{n}\right)$ was used in the probit model as shown in Equation (1).

Propensity score was defined as the conditional probability of receiving treatment given a vector of observable covariates (Rosenbaum \& Rubin, 1983). After the propensity score is estimated, each member of an agricultural cooperative was matched with non-members with similar propensity score values with the aim of estimating the average treatment effect on the treated (ATT), which is notated,

$$
A T T=E\left(Y_{1}-Y_{0} \mid x, D=1\right)=E\left(Y_{1} \mid x, D=1\right)-E\left(Y_{0} \mid x, D=1\right)
$$


where, $D$ is an indicator variable equal to 1 if the farmer is a member, $Y_{1}$ is the members' outcomes, $Y_{0}$ is the non-members' outcomes and $x$ is a vector of the control variables. Outcome variables used this study are paddy yield, paddy revenue, livestock revenue and farm revenue (Table 1).

After matching, a balancing test is required to verify that the differences in the control variables between member group and non-member group have been eradicated, in which the matched comparison group could be regarded as a credible counterfactual (Ali \& Abdulai, 2010). Even though there are many kinds of balancing tests, the most commonly adopted is the mean absolute standardized bias (MASB) method. Therefore, we used the MASB approach as recommended by Rosenbaum and Rubin (1983), in which the standardized difference should be smaller than $20 \%$ to prove the success in the matching procedure.

\subsection{Description of Data Variables}

Table 1 shows the variables used in this study, and it describes the variable names, definition and unit of each variable. Farmer status was used as the dependent variable while age, gender, education of household head, household size, paddy land size, paddy sale, annual income from off-farm jobs, TV, car, contact with extension workers and access to good road were used as independent variables in the probit model to identify factors influencing membership in agricultural cooperatives. Moreover, paddy yield, paddy revenue, livestock revenue and farm revenue were used as outcome variables in PSM.

Table 1. Definition of variables

\begin{tabular}{|c|c|c|}
\hline Variables & Definition & Unit \\
\hline \multicolumn{3}{|c|}{ Dependent variable (used in probit model) } \\
\hline Farmer status & \multicolumn{2}{|l|}{$1=$ Member of agricultural cooperative $; 0=$ non-member } \\
\hline \multicolumn{3}{|c|}{ Independent variables (used in probit model) } \\
\hline Age & Age of household head & Year \\
\hline Gender & Gender of household head; $1=$ male; $0=$ female & Dummy \\
\hline Education & Years of education of household head & Year \\
\hline Household size & Number of household members & Number \\
\hline Paddy land & Paddy land size & Hectare \\
\hline Paddy sale & Farmers who sell their paddy $=1 ; 0=$ otherwise & Dummy \\
\hline Off-farm & Annual income of household head from off-farm job & US \$ \\
\hline TV owned & Household having TV $=1 ; 0=$ otherwise & Dummy \\
\hline Car & Household having car $=1 ; 0=$ otherwise & Dummy \\
\hline Extension & Having contact with extension workers related to agricultural cooperatives $=1 ; 0=$ otherwise & Dummy \\
\hline Access to road & Access to good road in village $=1 ; 0=$ otherwise & Dummy \\
\hline \multicolumn{3}{|c|}{ Outcome variables (used in matching of propensity score) } \\
\hline Paddy yield & Yield per hectare & $\mathrm{Kg} / \mathrm{ha}$ \\
\hline Paddy revenue & Total revenue from paddy per hectare & US $\$ /$ ha \\
\hline Livestock revenue & Total revenue from animals (pigs and poultry) per year & US \$ \\
\hline Farm revenue & Total revenue from farm activities (paddy, crop, animal, aquaculture) per year & US $\$$ \\
\hline
\end{tabular}

\section{Results and Discussion}

\subsection{Descriptive Results before and after Matching}

Table 2 shows the characteristic differences between members and non-members before and after matching. Before matching, household size, paddy land size, paddy sale and contact with extension workers were significantly different between members and non-members. On average, household size of members was 4.68 while the household size of non-members was 3.83. Moreover, members had paddy land size of 0.97 hectare, and this is 0.19 hectare bigger than non-members. In addition, $0.82 \%$ of members sold their paddy, which was $0.19 \%$ higher than non-members. Based on the unmatched results, $0.87 \%$ of members been in contact with extension workers compared to only $0.08 \%$ of non-members having had contact with extension workers. Outcome variables including paddy yield, paddy revenue, livestock revenue and farm revenue are also presented in Table 2. Livestock revenues of members was US\$421.61 per year, which is US\$219.41 significantly higher than non-members. Also, members got farm revenues of US $\$ 1,291.26$ per year, US $\$ 322.83$ statistically more 
than non-members. From simple comparison, results suggest that members obtained higher livestock revenue and farm revenue than non-members before matching. However, the differences in outcomes before matching may be caused by characteristics differences rather than being a member. It may lead to biased conclusion if we do not control these differences. Thus, we employed PSM to control these differences of characteristics in order to get unbiased results.

The mean absolute standardized bias was $17.1 \%$ and as Rosenbaum and Rubin (1983) suggested that the mean absolute standardized bias should be smaller than $20 \%$, this confirms the success in the matching process. After matching, the differences between members and non-members were reduced. Only education and household size were still significant after we conducted matching process.

Table 2. Characteristic difference between members and non-members before and after matching

\begin{tabular}{|c|c|c|c|c|c|c|c|c|c|}
\hline \multirow[b]{2}{*}{ Variables } & \multicolumn{4}{|c|}{ Before matching } & \multicolumn{4}{|c|}{ After matching } & \multirow[b]{2}{*}{$\%$ Bias } \\
\hline & $\begin{array}{l}\text { Member } \\
\text { Mean }\end{array}$ & $\begin{array}{l}\text { Non-member } \\
\text { Mean }\end{array}$ & Diff. & Tests $^{1}$ & $\begin{array}{l}\text { Member } \\
\text { Mean }\end{array}$ & $\begin{array}{l}\text { Non-member } \\
\text { Mean }\end{array}$ & Diff. & Tests $^{1}$ & \\
\hline Age & 46.86 & 47.02 & -0.16 & -0.09 & 46.86 & 46.07 & 0.80 & 0.53 & 6.0 \\
\hline Gender & 0.89 & 0.90 & -0.01 & -0.15 & 0.89 & 0.93 & -0.04 & -0.99 & -13.0 \\
\hline Education & 5.93 & 5.41 & 0.52 & 1.28 & 5.93 & 4.32 & $1.61^{* * *}$ & 3.34 & 51.0 \\
\hline Household size & 4.68 & 3.83 & $0.85^{* * *}$ & 4.61 & 4.68 & 3.80 & $0.88^{* * *}$ & 4.55 & 61.0 \\
\hline Paddy land & 0.97 & 0.79 & $0.19^{* * *}$ & 2.84 & 0.97 & 0.85 & 0.12 & 1.53 & 22.1 \\
\hline Paddy sale & 0.82 & 0.63 & $0.19^{* * *}$ & 3.17 & 0.82 & 0.83 & -0.01 & -0.19 & -2.3 \\
\hline Off-farm & 368.43 & 427.78 & -59.35 & 0.57 & & & & & \\
\hline $\log$ (off-farm) & 1.02 & 1.17 & -0.15 & 0.82 & 1.02 & 1.11 & -0.09 & -0.43 & -6.3 \\
\hline TV owned & 0.92 & 0.93 & -0.01 & -0.32 & 0.92 & 0.88 & 0.04 & 0.94 & 15.0 \\
\hline Car & 0.02 & 0.03 & -0.01 & -0.38 & 0.02 & 0.03 & -0.01 & -0.45 & -6.6 \\
\hline Extension & 0.87 & 0.08 & $0.79^{* * *}$ & 12.36 & 0.87 & 0.87 & 0.00 & 0.00 & 0.0 \\
\hline Access to road & 0.39 & 0.38 & 0.01 & 0.15 & 0.39 & 0.37 & 0.02 & 0.29 & 4.1 \\
\hline Paddy yield & $2,889.08$ & $2,956.46$ & -67.38 & -1.17 & \multirow{4}{*}{\multicolumn{5}{|c|}{ Mean absolute standardized bias $=17.1$}} \\
\hline Paddy revenue & 815.57 & 822.22 & -6.65 & -0.28 & & & & & \\
\hline Livest. revenue & 421.61 & 288.73 & $219.41^{* * *}$ & 2.59 & & & & & \\
\hline Farm revenue & $1,291.26$ & 968.43 & $322.83^{* * *}$ & 3.54 & & & & & \\
\hline
\end{tabular}

Note. ${ }^{1}:{ }^{*}, * *, * *$ significant at $10 \%, 5 \%, 1 \%$ respectively; We used t-test for mean comparison and z-test for proportion comparison; Diff. is difference; Livest. revenue is livestock revenue.

Source: Own survey (2016).

\subsection{Determinants of Membership in Agricultural Cooperatives}

As the results of coefficients in the probit estimation could not be interpreted directly, the marginal effects of independent variables of becoming a member of agricultural cooperatives were used and are shown in Table 3, and the units of those marginal effects are the same as the units of measurement for the explanatory variables (Greene, 2013). According to the probit estimates in Table 3, paddy sale and having contact with extension workers are positively associated with the decision to become members of agricultural cooperatives, while a male-headed household and off-farm income are negatively associated. For gender of household heads, the result of marginal effects shows that if the household heads are males, the probability of becoming a member of agricultural cooperatives decrease by 0.11 (holding all other variables constant) compared to female household heads. This may be due to the fact that male household heads mostly have off-farm jobs, so they do not want to join. On the other hand, female-headed households are generally poor, so they want to join the cooperative to receive agricultural techniques and other services from the cooperatives. This is contrary to the finding of Bernard and Spielman (2009), and Abebaw and Haile (2013) who found that woman-headed households were less likely to join the cooperatives in Ethiopia. Also, Mayoux (1999) mentioned that females in Africa have a limited chance of joining in collective activities such as cooperatives. For paddy sale, the probability of becoming a member in agricultural cooperatives of farmers who sell their paddy increases by 0.09 (holding all other variables constant) compared to farmers who did not sell their paddy. This is because they want to acquire rice-growing techniques and want to sell their paddy for better prices. Based on the results of marginal effects, 
with one percent increase in off-farm income, the probability of becoming a member of agricultural cooperatives decreases by 0.06 (holding all other variables constant). Farmers who have higher off-farm income are less likely to join the cooperatives because they are busy with off-farm jobs, and rice is not their main source of income. This is consistent with the finding of Nugusse, Huylenbroeck, and Buysse (2012), who found that households with special skills other than farming were less likely to join the cooperatives in Northern Ethiopia. Moreover, farmers who have been in contact with extension workers are more likely to join the cooperatives because they had got the information on the benefits of the cooperatives, and their probability of becoming a member of an agricultural cooperative increases by 0.46 holding all other variables constant. This result is in line with Debeb and Haile (2016), who found that access to information on the benefits of agricultural cooperatives encouraged farmers to join the cooperatives.

Table 3. Results of the probit model for factors influencing membership in agricultural cooperatives

\begin{tabular}{|c|c|c|c|c|}
\hline \multirow{2}{*}{ Variables } & \multicolumn{2}{|c|}{ Probit estimates } & \multicolumn{2}{|c|}{ Marginal effects } \\
\hline & Coef. & Std. Err. & $\mathrm{Dy} / \mathrm{dx}$ & Std. Err. \\
\hline Age & $-4.49 \mathrm{E}-3$ & $1.04 \mathrm{E}-2$ & $6.77 \mathrm{E}-4$ & $1.58 \mathrm{E}-3$ \\
\hline Gender & $-0.76^{*}$ & 0.41 & $-0.11^{*}$ & 0.06 \\
\hline Education & 0.03 & 0.05 & 0.00 & 0.01 \\
\hline Household size & 0.05 & 0.10 & 0.01 & 0.02 \\
\hline Paddy land & -0.25 & 0.27 & -0.04 & 0.04 \\
\hline Paddy sale & $0.61^{*}$ & 0.36 & $0.09^{*}$ & 0.05 \\
\hline $\log$ (off-farm) & $-0.37^{* * *}$ & 0.12 & $-0.06^{* * *}$ & 0.02 \\
\hline TV owned & 0.08 & 0.47 & 0.01 & 0.07 \\
\hline Car & 0.35 & 0.69 & 0.05 & 0.10 \\
\hline Extension & $3.04^{* * *}$ & 0.33 & $0.46^{* * *}$ & 0.03 \\
\hline Access to road & 0.28 & 0.30 & 0.04 & 0.05 \\
\hline _cons & -1.07 & 0.88 & & \\
\hline Log likelihood & -67.07 & & & \\
\hline LR Chi ${ }^{2}$ & 193.29 & & & \\
\hline Pseudo $\mathrm{R}^{2}$ & 0.59 & & & \\
\hline
\end{tabular}

Note. $*, * *, * * *$ significant at $10 \%, 5 \%, 1 \%$, respectively.

Source: Own survey (2016).

\subsection{Impacts of Agricultural Cooperatives on Farmers' Revenues}

After matching, each member of the agricultural cooperatives was matched with non-members with similar propensity score values to estimate the average treatment effect for the treated (ATT) and average treatment effect for the untreated (ATU). The results of propensity score matching in Table 4 show that before matching, on average, paddy yields of members and non-members are $2,889.08 \mathrm{Kg} / \mathrm{ha}$ and $2956.46 \mathrm{Kg} / \mathrm{ha}$, and members and non-members have paddy revenues of US\$815.57 and US\$822.22 per hectare respectively. However, there are no significant differences before and after matching. These results suggest that membership in agricultural cooperatives has no impact on paddy yield and revenue as there is no significant difference between members and non-members with and without the matching process. This may be due to the fact that the agricultural cooperatives have not provided sufficient training, and members did not actively attend those trainings that were provided. Furthermore, the cooperatives have failed to provide better prices compared to other traders as they have small capital and the capability of the management committees is limited. This result is consistent with Afolami, Obayelu, Agbonlahor, and Lawal-Adebowale (2012), who also found no significant difference in yields between non-members and members of rice agricultural cooperatives in Nigeria. Similarly, Hoken and Su (2015) also found no significant difference in net income between participants and non-participants in rice-producing cooperatives in China. Being a member in agricultural cooperatives, members sampled could obtain US\$219.41 and US $\$ 403.42$ respectively from livestock and farm significantly higher than non-members. These results show the positive impact on livestock and farm revenues for members, according to ATT, but there is no impact for non-members if they join the cooperatives according to ATU. The cooperatives provide training on livestock production and encourage members to raise more livestock compared to non-members who have no or fewer 
livestock, so this leads to positive impacts. However, there is no impact on non-members if they join the cooperatives, as they have higher off-farm income, less paddy land size, and fewer laborers, conditions that are not favorable for them to undertake other farming activities.

Table 4. Results of propensity score matching

\begin{tabular}{|c|c|c|c|c|c|c|}
\hline Outcomes & Sample & Member & Non-member & Difference & S.E. & T-stat \\
\hline \multirow[t]{3}{*}{ Paddy yield } & Unmatched & $2,889.08$ & $2,956.46$ & -67.38 & 57.38 & -1.17 \\
\hline & ATT & $2,889.08$ & $2,944.68$ & -54.98 & 193.63 & -0.28 \\
\hline & ATU & $2,861.17$ & $2,956.46$ & -95.30 & 158.89 & -0.60 \\
\hline \multirow[t]{3}{*}{ Paddy revenue } & Unmatched & 815.57 & 822.22 & -6.65 & 23.96 & -0.28 \\
\hline & ATT & 815.57 & 818.07 & -2.51 & 60.18 & -0.04 \\
\hline & ATU & 718.76 & 822.22 & $-103.45^{* *}$ & 47.31 & -2.19 \\
\hline \multirow[t]{3}{*}{ Livestock revenue } & Unmatched & 421.61 & 288.73 & $132.88^{* * *-}$ & 51.33 & 2.59 \\
\hline & ATT & 421.61 & 202.19 & $219.41^{* * *}$ & 84.60 & 2.59 \\
\hline & ATU & 299.08 & 288.73 & 10.36 & 74.16 & 0.14 \\
\hline \multirow[t]{3}{*}{ Farm revenue } & Unmatched & $1,291.26$ & 968.43 & $322.83^{* * \pi^{-}}$ & 91.16 & 3.54 \\
\hline & ATT & $1,291.26$ & 887.84 & $403.42^{*}$ & 214.20 & 1.88 \\
\hline & ATU & 904.85 & 968.43 & -63.59 & 290.33 & -0.22 \\
\hline
\end{tabular}

Note. ${ }^{*}, * *, * * *$ significant at $10 \%, 5 \%, 1 \%$, respectively; S.E. is standard error. ATT: average treatment effect for the treated; ATU: average treatment effect for the untreated.

Source: Own survey (2016).

\section{Conclusion and Policy Implications}

In conclusion, farmers who sold their paddy and farmers who had contact with extension workers are more likely to join the cooperatives. Male farmers and higher off-farm-income farmers are less likely to join the cooperatives. Agricultural cooperatives have no impact on paddy yield and paddy revenue, but there are positive impacts on livestock and farm revenues for members as they can increase their livestock and other agricultural production when obtaining agricultural training from the cooperatives. However, there is no impact on non-members if they join the cooperatives, as they have higher off-farm income, less paddy land size and fewer laborers, which are not favorable to undertaking other farming activities.

Based on the results of this study, some recommendations can be drawn. The extension workers should disseminate the benefits of agricultural cooperatives to farmers more widely. Moreover, the cooperatives should focus more on farmers who have no or lower off-farm income and female-headed households and encourage farmers to commercialize themselves in rice and other agricultural activities to gain more benefits from agricultural cooperatives. Furthermore, agricultural cooperatives should provide more training on rice production and encourage members to actively join such training. Moreover, the cooperatives should strengthen and expand paddy markets to get better prices for their members through some means such as contract farming with millers. Additionally, the capital of the cooperatives should be increased to sustain their management system and to enable them to compete with other traders. Relevant institutions should provide capacity-building training or study tours to management committees, and management committees should be regularly monitored and advised by technical officers from the government or NGOs.

\section{Acknowledgements}

The authors would like to acknowledge Mr. Rada Khoy, a graduate student of Kyushu University, for assisting in this study and providing comments to improve the manuscript. Moreover, we would like to thank the editor and anonymous reviewers for constructive comments on this article.

\section{References}

Abebaw, D., \& Haile, M. G. (2013). The impact of cooperatives on agricultural technology adoption: Empirical evidence from Ethiopia. Food Policy, 38, 82-91. https://doi.org/10.1016/j.foodpol.2012.10.003

Afolami, C. A., Obayelu, A. E., Agbonlahor, M. U., \& Lawal-Adebowale, O. A. (2012). Socioeconomic Analysis of Rice Farmers and Effects of Group Formation on Rice Production in Ekiti and Ogun States of South-West Nigeria. Journal of Agricultural Science, 4(4), 233-244. https://doi.org/10.5539/jas.v4n4p233 
Ali, A., \& Abdulai, A. (2010). The adoption of genetically modified cotton and poverty reduction in Pakistan. Journal of Agricultural Economics, 61(1), 175-192. https://doi.org/10.1111/j.1477-9552.2009.00227.x

Asian Development Bank (ADB). (2014). Cambodia Country Poverty Analysis 2014. Retrieved October 30, 2017, from https://www.adb.org/sites/default/files/institutional-document/151706/cambodia-country-povert y-analysis-2014.pdf

Becker, S. O., \& Ichino, A. (2002). Estimation of Average Treatment Effects Based on Propensity Score. The Stata Journal, 2(4), 358-377.

Bernard, T., \& Spielman, D. J. (2009). Reaching the rural poor through rural producer organizations? A study of agricultural marketing cooperatives in Ethiopia. Food Policy, 34, 60-69. https://doi.org/10.1016/j.foodpol. 2008.08.001

Debeb, D., \& Haile, M. (2016). A Study on Factors Affecting Farmers' Cooperative Membership Increment in Bench Maji Zone, Southwestern Ethiopia. Developing Country Studies, 6(2), 129-138.

Food and Agriculture Organization of the United Nations (FAO). (2014). FAPDA country fact sheet on food and agriculture policy trends-Cambodia. Retrieved October 26, 2017, from http://www.fao.org/docrep/field/ 009/i3761e/i3761e.pdf

Greene, W. H. (2013). Econometric Analysis (7th ed.). New York: New York University Press.

Hoken, H., \& Su, Q. (2015). Measuring the Effect of Agricultural Cooperatives on Household Income Using PSM-DID: A Case Study of a Rice-Producing Cooperative in China. IDE Discussion Paper No. 539. Retrieved from http://www.ide.go.jp/English/Publish/Download/Dp/539.html

Mayoux, L. (1999). Questioning virtuous spirals: microfinance and women's empowerment in Africa. Journal of International Development, 11, 957-984. https://doi.org/10.1002/(SICI)1099-1328(199911/12)11:7\%3C957:: AID-JID623\%3E3.0.CO;2-\#

Ministry of Agriculture, Forestry and Fisheries (MAFF). (2008). Current status of agricultural cooperatives in Cambodia. Phnom Penh.

Ministry of Agriculture, Forestry and Fisheries (MAFF). (2015). Agricultural Sector Strategic Development Plan 2014-2018. Phnom Penh.

Ministry of Agriculture, Forestry and Fisheries (MAFF). (2016). Annual Report for Agriculture, Forestry and Fisheries 2015-2016 and Direction 2016-2017. Phnom Penh.

Monteiro, N. (2010). Using propensity matching estimators to evaluate the impact of privatization on wages. Applied Economics, 42, 1293-1313. https://doi.org/10.1080/00036840701721281

National Committee for Sub-National Democratic Development (NCDD). (2010). Commune Database Online: District/Khan Profile-Tramkak. Retrieved July 7, 2017, from http://www.ncdd.gov.kh

National Institute of Statistics (NIS). (2013). Cambodia Inter-Censal Population Survey 2013 Final Report. Phnom Penh.

Nugusse, W. Z., Huylenbroeck, G. V., \& Buysse, J. (2013). Determinants of rural people to join cooperatives in Northern Ethiopia. International Journal of Social Economics, 40(12), 1094-1107. https://oi.org/10.1108/ IJSE-07-2012-0138

Rosenbaum, P., \& Rubin, D. (1983). The central role of the propensity score in observational studies for causal effects. Biometrika, 70, 41-55. https://doi.org/10.1093/biomet/70.1.41

\section{Copyrights}

Copyright for this article is retained by the author(s), with first publication rights granted to the journal.

This is an open-access article distributed under the terms and conditions of the Creative Commons Attribution license (http://creativecommons.org/licenses/by/4.0/). 